\title{
APLIKASI TEKNIK SPHERIFICATION PADA COATING SARI BUAH JERUK
}

\section{APPLICATION OF SPHERIFICATION TECHNIQUE ON COATING OF ORANGE EXTRACT}

\author{
Indah Yuliasih, Sugiarto, dan Melisa Constantia \\ Departemen Teknologi Industri Pertanian, Fakultas Teknologi Pertanian, Institut Pertanian Bogor \\ Kampus IPB Darmaga, PO Box 220, Bogor, Jawa Barat, Indonesia. \\ email: ind_yul@yahoo.com \\ Makalah: Diterima 8 April 2015; Diperbaiki 2 Agustus 2017; Disetujui 10 September 2017
}

Fruit extract coating is an innovative food product which created by spherification technique involved adding a small quantity of sodium alginate into a fruit extract and carefully dropping this liquid into calcium chloride solution. The fruit extract came in contact with the calcium chloride solution created a sphere. The objectives of this research were to find the best formulation of sodium alginate (0.6, 0.7, and 0.8\%), calcium chloride (0.6 and 0.7\%), and glucose solution (15 and $22.5^{\circ}$ brix) for producing orange extract coating, and to analyze their characteristics. The best formula based on consumer hedonic test was $0.8 \%$ sodium alginate, $0.7 \%$ calcium chloride, and $15^{\circ}$ brix glucose solution. In this formula, orange extrac coating had total acid of 112 $\mathrm{mg} / 100 \mathrm{~g}, 6.56 \%$ total glucose, $48.4 \mathrm{mg} / 100 \mathrm{~g}$ vitamin C, and total suspended solids of $1033.33 \mathrm{mg} / \mathrm{L}$.

Keywords: orange extract coating, spherification, sodium alginat and calcium chloride

\section{ABSTRAK}

Coating sari buah adalah produk makanan yang inovatif yang dibuat dengan teknik spherification dengan menambahkan sejumlah kecil natrium alginat dalam sari buah dan dengan hati-hati menjatuhkan cairan tersebut ke dalam larutan kalsium klorida. Sari buah kontak dengan larutan kalsium klorida membentuk sebuah bola. Tujuan dari penelitian ini adalah mendapatkan formulasi terbaik dari natrium alginat $(0,6 ; 0,7$ dan $0,8 \%)$, kalsium klorida (0,6 dan 0,7\%) dan larutan glukosa (15 dan 22,5 brix) untuk memproduksi coating sari buah jeruk, dan menganalisis karakteristiknya. Formula terbaik berdasarkan uji kesukaan konsumen adalah natrium alginat $0,8 \%$, kalsium klorida $0,7 \%$, dan larutan glukosa $15^{\circ}$ brix. Hasil coating sari buah jeruk memiliki total asam $112 \mathrm{mg} / 100 \mathrm{~g}$ bahan, total gula 6,56\%, vitamin C 48,4 mg/100 g bahan, dan total padatan terlarut 1033,33 $\mathrm{mg} / \mathrm{L}$.

Kata kunci: coating sari buah jeruk, spherification, natrium alginat dan kalsium klorida

\section{PENDAHULUAN}

Buah jeruk merupakan salah satu jenis buah yang memiliki prospek yang baik untuk dikembangkan karena telah dikenal oleh masyarakat luas. Selain itu, jeruk memiliki citarasa, aroma, kesegaran, dan sumber vitamin bagi tubuh sehingga sangat disukai oleh konsumen. Masyarakat Indonesia umumnya mengonsumsi jeruk dalam bentuk segar. Saat ini sebagian besar konsumsi buah jeruk dimakan secara langsung maupun diperas terlebih dahulu untuk diambil sarinya.

Salah satu inovasi produk olahan dengan bahan baku buah jeruk adalah coating sari buah jeruk dengan teknik spherification. Spherification adalah suatu teknik yang menciptakan produk makanan dengan bagian luar permukaan berbentuk semi solid dengan bagian dalamnya berwujud cair (Mc.Hugh, 2003). Spherification termasuk kedalam metode pembentukan gel secara difusi. Menurut Kirk dan Othmer (1994) metode difusi merupakan teknik pembentukan gel dilakukan oleh ion-ion kalsium melalui proses difusi ke dalam larutan alginat. Oleh karena proses difusi tersebut berlangsung lambat, maka cara seperti ini hanya efektif digunakan untuk membentuk lapisan gel yang tipis pada permukaan produk. This (2006) menjelaskan bahan utama yang digunakan adalah narium alginat dan kalsium klorida. Pada saat natrium alginat kontak dengan ion kalsium, terjadi proses pembekuan di bagian luar. Semakin lama produk tersebut didiamkan dalam larutan kalsium klorida, maka bagian dalam yang berbentuk cair akan membentuk gel dan bagian cairannya akan semakin sedikit.

Natrium alginat banyak digunakan pada industri makanan maupun farmasi untuk pembentukan gel dengan adanya reaksi dengan kation diavalen seperti $\mathrm{Ca}^{2+}$ (Brownlee et al., 2005; Josef et al., 2010; Li et al., 2011). Jika alginat dilarutkan dengan larutan kalsium klorida segera terbentuk gel kalsium alginat yang tidak larut dalam air. Ikatan antara kalsium dengan alginat adalah ikatan khelat yaitu antara kalsium dengan rantai Lguluronat dari alginat (Smidsrod dan Draget, 1996).

Saat ini produk olahan ini belum banyak ditemukan di Indonesia. Dalam penelitian ini digunakan buah jeruk siam madu Karo atau lebih dikenal dengan sebutan jeruk Medan sebagai bahan sari buah karena kandungan gizi yang terkandung di dalamnya. Selain mendapatkan sensasi yang baru dalam produk ini, konsumen juga mendapatkan 
manfaat dari kandungan buah di dalamnya. Menurut Khotimchenko dan Khotimchenko (2004), kalsium alginat berguna sebagai hepatoprotektor (pelindung hati atau memulihkan hati setelah dirusak oleh racun).

Tujuan penelitian ini adalah mendapatkan kondisi proses dan formula terbaik dalam pembuatan coating sari buah jeruk Medan, serta mengetahui mutu produk berdasarkan kadar vitamin $\mathrm{C}$, total asam, total gula, dan total suspended solids (TSS).

\section{BAHAN DAN METODE}

\section{Bahan dan Alat}

Bahan-bahan yang digunakan dalam penelitian ini adalah natrium alginat, kalsium klorida, glukosa cair, jeruk Medan, dan air mineral. Peralatan yang dibutuhkan adalah mixer, juicer, spherification kit, gelas piala, peralatan analisis seperti buret dan spectrofotometer.

\section{Metode}

\section{Karakterisasi Buah Jeruk Medan}

Karakterisasi dilakukan untuk mengetahui kandungan gizi buah jeruk Medan yang akan digunakan pada penelitian ini. Karakterisasi ini merupakan acuan awal dari analisis yang akan dilakukan terhadap coating sari buah jeruk Medan yang dihasilkan, sehingga dapat diketahui perubahan-perubahan karakteristik yang terjadi. Parameter yang diuji terdiri dari kadar air (AOAC, 1997), serat (AOAC, 1997), protein (AOAC, 1997), abu (AOAC, 1997), total asam (AOAC, 1997), total gula (Dubois et al., 1956), vitamin C (Gardjito dan Wardana, 2003), dan pH (Okezie dan Bello, 1988).

\section{Pembuatan Coating Sari Jeruk Medan}

Pembuatan coating sari buah jeruk diawali dengan pencampuran sari buah jeruk Medan dengan natrium alginate. Pencampuran ini menghasilkan busa yang harus dihilangkan terlebih dahulu dengan penyaringan. Setelah dilakukan penyaringan, campuran larutan sari buah jeruk dan natrium alginat kemudian dijatuhkan secara berlahan-lahan ke larutan kalsium klorida. Teknik spherification pada coating sari buah jeruk disajikan pada Gambar 1. Coating sari buah jeruk yang terbentuk disimpan dalam larutan glukosa. Konsentrasi natrium alginat yang diujikan adalah 0,$5 ; 0,6$ dan $0,7 \%$ dengan kombinasi konsentrasi kalsium klorida 0,5; 0,6 dan $0,7 \%$. Penentuan formula terbaik dipilih berdasarkan pengamatan visual terhadap bentuk coating sari buah jeruk yang dihasilkan.

Penentuan konsentrasi larutan glukosa dilakukan dengan menguji kadar gula campuran sari buah jeruk dan natrium alginat. Kadar gula campuran tersebut kemudian dilakukan penyetaraan dengan kadar gula larutan glukosa. Pemilihan konsentrasi kadar gula dari larutan glukosa didasarkan pada daya tahan larutan untuk mempertahankan bentuk dan warna coating sari buah jeruk.

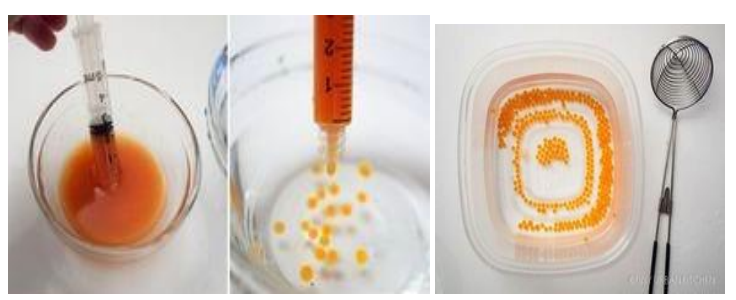

Gambar 1. Teknik spherification pada coating sari buah jeruk

\section{Karakterisasi Produk}

Karakterisasi produk dilakukan pada campuran sari buah jeruk dan natrium alginat, coating sari buah jeruk yang disimpan pada larutan glukosa yang diamati pada jam ke-0 dan jam ke-3. Parameter yang diamati meliputi vitamin C (Gardjito dan Wardana, 2003), total asam (AOAC, 1997), total gula (Dubois et al., 1956), total suspended solids (TSS), dan uji kesukaan 30 orang panelis semi terlatih (warna, rasa, aroma, bentuk, kekenyalan, dan after taste) (Soekarto, 1985).

\section{HASIL DAN PEMBAHASAN}

\section{Karakteristik Jeruk Medan}

Jeruk Medan yang digunakan sebagai bahan baku diperoleh dari pasar di daerah Bogor. Karakterisasi ini merupakan acuan awal dari analisis yang akan dilakukan terhadap produk coating sari buah jeruk yang dihasilkan. Karakteristik buah jeruk Medan dapat dilihat pada Tabel 1.

Tabel 1. Karakteristik mutu buah jeruk Medan

\begin{tabular}{lr}
\hline Karakteristik & Hasil uji \\
\hline Kadar air (\%) & 90,13 \\
Kadar abu (\%) & 0,99 \\
Kadar protein (\%) & 0,87 \\
Kadar serat (\%) & 3,29 \\
Total asam (mg/100 g bahan) & 272,00 \\
Total gula (\%) & 8,23 \\
Vitamin C (mg/100 g bahan) & 61,60 \\
pH & 4 \\
\hline
\end{tabular}

Kadar air jeruk Medan yang tinggi dan kadar seratnya yang cukup rendah sesuai untuk dijadikan bahan pembuatan coating sari buah. Kadar serat diduga dapat menyebabkan sulitnya pembentukan coating sari buah jeruk (Hill, 2009). Rasa jeruk Medan yang manis dan kandungan vitamin $\mathrm{C}$ yang tinggi menjadi kelebihan tersendiri dari jeruk lokal.

Pengaruh Konsentrasi Natrium Alginat dan Kalsium Klorida terhadap Bentuk Coating Sari Buah Jeruk Medan

Penentuan konsentrasi natrium alginat yang diujikan adalah 0,5;0,6 dan 0,7\% dan konsentrasi 
kalsium klorida 0,5; 0,6 dan 0,7\%. Penampakan visual coating sari buah jeruk Medan pada berbagai konsentrasi natrium alginat dan kalsium klorida dapat dilihat pada Tabel 2 .

Kombinasi natrium alginat $0,5 \%$ dengan kalsium klorida 0,$5 ; 0,6$ dan $0,7 \%$ tidak menunjukkan hasil yang baik sehingga konsentrasi natrium alginat $0,5 \%$ tidak diujikan pada tahap selanjutnya. Pada konsentrasi natrium alginat $0,5 \%$, coating sari buah jeruk cenderung sulit terbentuk dan dihasilkan bentuk yang melebar. Perlakuan kombinasi konsentrasi alginat $0,6 \%$ dengan kalsium klorida 0,$5 ; \quad 0,6$ dan $0,7 \%$ menunjukkan pembentukan bulatan coating sari buah jeruk lebih mudah dan penampakan visual yang cukup baik. Konsentrasi natrium alginat $0,6 \%$ menjadi batas minimum dalam formula pembuatan coating sari buah jeruk Medan. Perlakuan kombinasi konsentrasi natrium alginat $0,7 \%$ dengan kalsium klorida 0,5 ; 0,6 dan $0,7 \%$ menunjukkan pembentukan coating sari buah jeruk yang bulat sempurna.

Berdasarkan uraian tersebut di atas, untuk penelitian selanjutnya konsentrasi natrium alginat dipilih rentang bawah $0,6 \%$ dan rentang atas $0,8 \%$. Konsentrasi natrium alginat terpilih adalah 0,6;0,7 dan $0,8 \%$, sedangkan konsentrasi kalsium klorida terpilih adalah 0,6 dan $0,7 \%$.

\section{Pengaruh Konsentrasi Larutan Glukosa terhadap Bentuk Coating Sari Buah Jeruk Medan}

Larutan glukosa berfungsi sebagai media penyimpan produk coating sari buah. Media penyimpan ini diharapkan dapat mempertahankan warna dan menjaga bentuk coating sari buah jeruk agar tidak berubah akibat proses sineresis dan swelling. Kadar gula campuran natrium alginat dan sari buah jeruk adalah $7,5^{\circ}$ brix. Berdasarkan hasil tersebut dipilih tiga konsentrasi larutan glukosa berdasarkan kelipatannya, yaitu 7,5; 15, dan $22,5^{\circ}$ brix. Penampakan visual coating sari buah jeruk pada berbagai konsentrasi larutan glukosa dapat dilihat pada Gambar 2.

Pada Gambar 2 terlihat bahwa coating sari buah jeruk dalam larutan glukosa 7,5 ${ }^{\circ}$ brix menunjukkan perubahan bentuk, yaitu mengembang (swelling) dan warna yang tidak mengkilap, tetapi pada tingkat konsentrasi glukosa 15 dan 22,5 ${ }^{\circ}$ brix produk cenderung dapat mempertahankan bentuk dan warna yang mengkilap. Menurut Kaban et al. (2006), swelling adalah peningkatan volume suatu material pada saat kontak dengan cairan, gas, atau uap. Swelling terjadi karena adanya termodinamika yang bersesuaian antara rantai polimer dan air serta adanya gaya tarik yang disebabkan efek ikatan silang yang terjadi pada rantai polimer. Ketika membran kalsium alginat mengembang, mobilitas rantai polimer bertambah sehingga memudahkan penetrasi pelarut.

Selain itu ion-ion kecil yang terperangkap dalam membran, berdifusi meninggalkan membran sehingga memberikan peluang lebih besar bagi pelarut untuk mengisi ruang-ruang kosong yang ditinggalkan. Swelling pada coating sari buah jeruk ini kemungkinan disebabkan masih adanya ion $\mathrm{COO}^{-}$yang bersifat hidrofilik dalam membran.

Tabel 2. Bentuk coating sari buah jeruk Medan pada berbagai konsentrasi natrium alginat dan kalsium klorida

\begin{tabular}{|c|c|c|c|}
\hline \multirow{2}{*}{$\begin{array}{c}\text { Konsentrasi natrium } \\
\text { alginat }(\%)\end{array}$} & \multicolumn{3}{|c|}{ Konsentrasi kalsium klorida (\%) } \\
\hline & 0,5 & 0,6 & 0,7 \\
\hline \multirow{2}{*}{0,5} & Bentuk melebar & Bentuk melebar & Bentuk melebar \\
\hline & $\begin{array}{l}\text { Bentuk bulat tetapi tidak } \\
\text { cukup stabil }\end{array}$ & $\begin{array}{l}\text { Bentuk bulat tetapi tidak } \\
\text { cukup stabil }\end{array}$ & $\begin{array}{l}\text { Bentuk bulat tetapi } \\
\text { tidak cukup stabil }\end{array}$ \\
\hline \multirow[t]{2}{*}{0,6} & & & \\
\hline & $\begin{array}{l}\text { Bentuk bulat dan tidak } \\
\text { cukup stabil }\end{array}$ & Bentuk bulat dan stabil & Bentuk bulat dan stabil \\
\hline \multirow[t]{2}{*}{0,7} & & & \\
\hline & $\Leftrightarrow$ & & $\Rightarrow$ \\
\hline
\end{tabular}




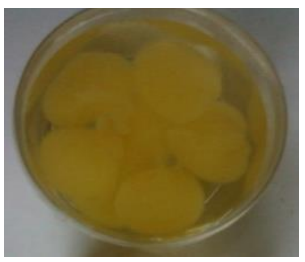

(a)

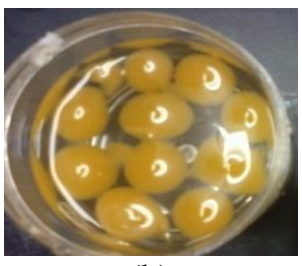

(b)

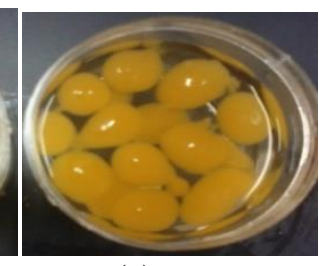

(c)

Gambar 2. Coating sari buah jeruk dalam larutan glukosa dengan konsentrasi (A) 7,5, (B) 15 dan (C) $22,5^{\circ}$ brix

Pada konsentrasi larutan glukosa 15 dan 22,5 obrix, coating sari buah jeruk cenderung dapat mempertahankan bentuk atau tidak terjadi swelling. Hal ini diduga gaya tarik yang disebabkan efek ikatan silang tidak cukup kuat untuk menarik larutan glukosa untuk masuk ke dalam produk. Oleh karena itu coating sari buah jeruk pada konsentrasi larutan glukosa 15 dan $22,5^{\circ}$ brix lebih mengkilap dan dapat mempertahankan bentuk dibandingkan pada larutan glukosa $7,5^{\circ}$ brix. Konsentrasi 15 dan 22,5 ${ }^{\circ}$ brix dipilih sebagai media penyimpan coating sari jeruk.

\section{Karakteristik Coating Sari Buah Jeruk Medan Vitamin C}

Penurunan kadar vitamin $\mathrm{C}$ terjadi mulai dari campuran sari buah jeruk dan natrium alginat, coating sari buah jeruk dalam perendaman larutan glukosa jam ke-0 dan ke-3. Vitamin C coating sari buah jeruk pada berbagai perlakuan dalam larutan glukosa jam ke-0 berkisar 33-39,6 mg/100 g bahan dan jam ke-3 berkisar 24,2-35,2 mg/100g bahan, lebih rendah dari vitamin $\mathrm{C}$ campuran sari buah jeruk dan natrium alginat (44-48,4 mg/100 g bahan). Kandungan vitamin $\mathrm{C}$ buah jeruk Medan sebesar $52,80 \mathrm{mg} / 100 \mathrm{~g}$ bahan sehingga terjadi penurunan 25-37,5\% vitamin $\mathrm{C}$ pada coating sari buah jeruk. (Gambar 3).

Penurunan vitamin C lebih cenderung disebabkan oleh pengaruh dari luar yaitu, temperatur, oksidasi, dan vitamin $\mathrm{C}$ yang larut dalam air. Semakin lama penyimpanan semakin banyak pengaruh dari luar yang dapat mempengaruhi vitamin C. Suhu pada larutan glukosa yang berfungsi sebagai media penyimpan perlu diperhatikan agar tidak terlalu tinggi karena dapat menyebabkan degradasi vitamin $\mathrm{C}$.

\section{Total Asam}

Total asam coating sari buah jeruk dalam larutan glukosa jam ke-0 pada berbagai perlakuan berkisar 88-152 mg/100 g bahan lebih rendah dari total asam campuran sari buah jeruk dan natrium alginat yang berkisar 228-284 mg/100 g bahan. Total asam coating sari buah jeruk dalam larutan glukosa jam ke-3 berkisar 60-92 mg/100 g bahan. Kandungan total asam buah jeruk Medan sebesar $272 \mathrm{mg} / 100 \mathrm{~g}$ bahan. Total asam mengalami penurunan sebesar $44,12-67,64 \%$. Penurunan total asam ini terjadi pada semua perlakuan. (Gambar 4).

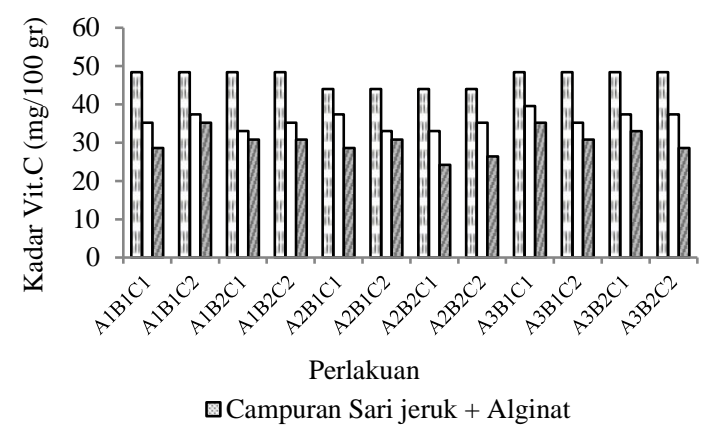

\begin{tabular}{|c|c|c|c|c|c|}
\hline \multicolumn{6}{|c|}{ Keterangan: } \\
\hline A1 & : & Natrium alginat $0,6 \%$ & B2 & $:$ & $\begin{array}{l}\text { Kalsium klorida } \\
0,7 \%\end{array}$ \\
\hline B1 & $:$ & $\begin{array}{l}\text { Kalsium } \\
0,6 \%\end{array}$ & $\mathrm{C} 2$ & $:$ & $\begin{array}{l}\text { Larutan glukosa } \\
22,5^{\circ} \text { brix }\end{array}$ \\
\hline $\mathrm{C} 1$ & $:$ & $\begin{array}{l}\text { Larutan glukosa } 15 \\
\text { obrix }\end{array}$ & A3 & $:$ & $\begin{array}{l}\text { Natrium alginat } \\
0,8 \%\end{array}$ \\
\hline A2 & & Natrium alginat $0,7 \%$ & & & \\
\hline
\end{tabular}

Gambar 3. Histogram kadar vitamin C (mg/100 g bahan) campuran sari buah jeruk dan natrium alginat, coating sari buah jeruk dalam larutan glukosa jam ke-0 dan ke-3

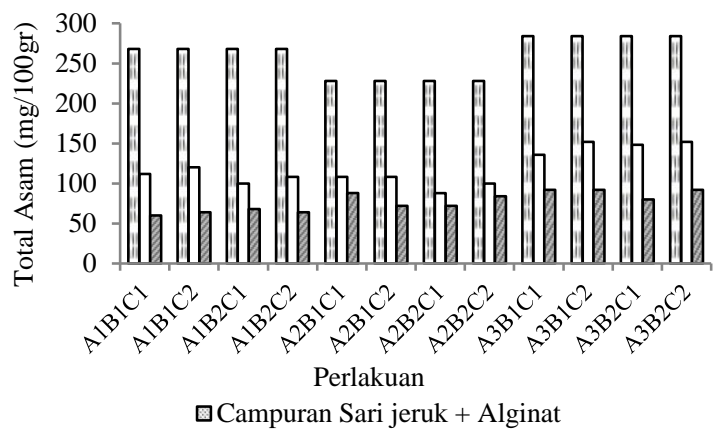

\begin{tabular}{|c|c|c|c|c|c|c|}
\hline \multicolumn{7}{|c|}{ Keterangan: } \\
\hline \multirow[t]{2}{*}{ A1 } & : & Natrium & alginat & $\mathrm{B} 2$ & : & Kalsium klorida \\
\hline & & $0,6 \%$ & & & & $0,7 \%$ \\
\hline \multirow[t]{2}{*}{ B1 } & : & Kalsium & klorida & $\mathrm{C} 2$ & : & Larutan glukosa \\
\hline & & $0,6 \%$ & & & & $22,5^{\circ}$ brix \\
\hline \multirow[t]{2}{*}{$\mathrm{C} 1$} & : & Larutan & glukosa 15 & A3 & : & Natrium alginat \\
\hline & & brix & & & & $0,8 \%$ \\
\hline \multirow[t]{2}{*}{ A2 } & & Natrium & alginat & & & \\
\hline & & $0,7 \%$ & & & & \\
\hline
\end{tabular}

Gambar 4. Histogram kadar total asam (mg/100g bahan) campuran sari buah jeruk dan natrium alginat, coating sari buah jeruk dalam larutan glukosa jam ke-0 dan ke-3

Penurunan total asam terjadi karena penyimpanan coating sari buah jeruk dalam larutan glukosa. Kontak yang terjadi antara coating sari 
buah jeruk dengan larutan glukosa menyebabkan terjadinya tekanan osmotik karena adanya perbedaan konsentrasi larutan glukosa. Berdasarkan analisis ragam, konsentrasi larutan glukosa memberikan pengaruh yang berbeda nyata $(\mathrm{P}>0,05)$ terhadap total asam coating sari buah eruk yang dihasilkan. Uji lanjut Least Significant Difference (LSD) menyatakan bahwa larutan glukosa $15^{\circ}$ brix memberikan pengaruh yang berbeda nyata dengan larutan glukosa $22,5^{\circ}$ brix. Pada larutan glukosa $22,5^{\circ}$ brix, total asam coating sari buah jeruk lebih kecil dibandingkan dengan coating sari buah jeruk pada larutan glukosa $15^{\circ}$ brix. Penggunaan konsentrasi glukosa yang tinggi cenderung menurunkan total asam coating sari buah jeruk. Hal ini diduga disebabkan oleh tekanan osmotik dari glukosa dengan konsentrasi $22,5^{\circ}$ brix lebih tinggi sehingga mampu menarik keluar cairan dalam coating sari buah jeruk lebih banyak dibandingkan dengan larutan yang konsentrasi glukosanya lebih rendah.

\section{Total Gula}

Histogram perubahan total gula menunjukkan terjadinya kecenderungan peningkatan total gula dari campuran sari buah jeruk dan natrium alginat ke coating sari buah jeruk. Total gula campuran sari buah jeruk dan natrium alginat berkisar 6,45-7,02\%. Total gula pada berbagai perlakuan coating sari buah jeruk dalam larutan gluksa jam ke-0 berkisar 5,40-8,47\% dan jam ke-3 berkisar 6,97-9,34\%. Kandungan total gula buah jeruk Medan sebesar 6,56\% sehingga terjadi peningkatan 0,04-22,55\%. Meningkatnya total gula ini dikarenakan lamanya waktu kontak (3 jam) coating sari buah jeruk dengan larutan glukosa. Lamanya waktu kontak ini menyebabkan kandungan gula dalam coating sari buah jeruk semakin meningkat. Selama perendaman coating sari buah jeruk dalam larutan glukosa terjadi penetrasi larutan glukosa ke dalam membran coating sari buah jeruk yang menyebabkan total gulanya meningkat.

Hasil analisis ragam menujukkan adanya pengaruh konsentrasi larutan glukosa berbeda nyata terhadap coating sari buah jeruk. Coating sari buah jeruk dalam larutan glukosa $22,5^{\circ}$ brix mempunyai total gula lebih besar dibandingkan dalam larutan glukosa $15^{\circ}$ brix. Semakin besar konsentrasi larutan glukosa yang digunakan maka total gula coating sari buah jeruk akan semakin besar pula. Hal ini diduga adanya proses difusi glukosa ke dalam coating sari buah jeruk selama perendaman dalam larutan glukosa.

Analisis ragam juga menunjukkan bahwa terdapat pengaruh nyata interaksi konsentrasi natrium alginat dengan konsentrasi kalsium klorida terhadap total gula coating sari buah jeruk yang dihasilkan. Total gula coating sari buah jeruk tertinggi terdapat pada konsentrasi natrium alginat $0,6 \%$ dan konsentrasi kalsium klorida $0,6 \%$. Total gula coating sari buah jeruk terendah terdapat pada konsentrasi natrium alginat $0,8 \%$ dan konsentrasi kalsium klorida $0,6 \%$. Semakin tinggi konsentrasi natrium alginat dan kalsium klorida yang digunakan maka coating sari buah jeruk yang dihasilkan lebih cepat mengalami proses gelasi dan bagian permukaannya lebih tebal oleh gel. Struktur gel yang kuat terbentuk di permukaan jaringan membran coating sari buah jeruk yang menyebabkan penghambatan penetrasi sehingga total gula yang dihasilkan lebih rendah. (Gambar 5).

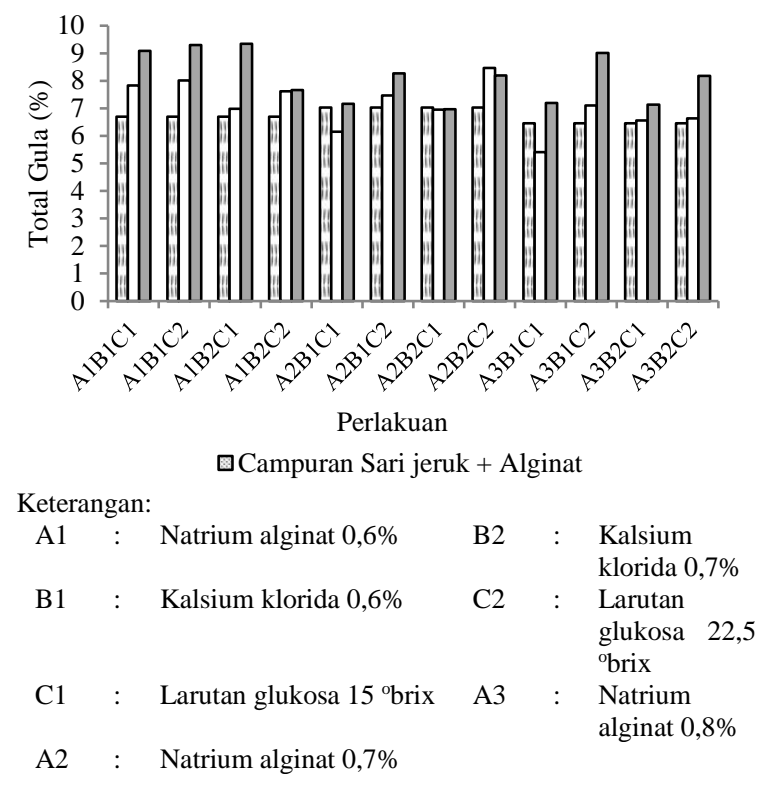

Gambar 5. Histogram kadar total gula (\%) campuran sari buah jeruk dan natrium alginat, coating sari buah jeruk dalam larutan glukosa jam ke-0 dan ke-3

\section{Total Suspended Solids (TSS)}

Pada Gambar 6, terlihat bahwa TSS mengalami penurunan dari campuran sari buah jeruk dan alginat ke coating sari buah jeruk dalam larutan glukosa jam ke-3. TSS campuran sari buah jeruk dan natrium alginat berkisar 1500-1658,33 mg/L dan pada berbagai perlakuan coating sari buah jeruk dalam larutan glukosa jam ke-0 berkisar 841,67$1433,33 \mathrm{mg} / \mathrm{L}$. Nilai TSS semakin menurun pada coating sari buah jeruk dalam larutan glukosa jam ke-3 yang berkisar 775-1025 mg/L. Penurunan TSS dari campuran sari buah jeruk dan natrium alginat ke coating sari buah jeruk sebesar 4,44-49,24\%.

TSS merupakan zat-zat padat yang berada dalam suspensi. Materi yang tersuspensi adalah materi yang mempunyai ukuran lebih besar daripada molekul/ion yang terlarut. Campuran sari buah jeruk dan natrium alginat mengalami perubahan fase menjadi sol (koloid yang mempunyai padatan tersuspensi dalam larutannya) dan kemudian menjadi gel (koloid tetapi mempunyai fraksi solid yang lebih besar daripada sol).

Analisis ragam terhadap TSS coating sari buah jeruk menunjukkan adanya pengaruh yang 
nyata $(\mathrm{p}>0,05)$ antara interaksi konsentrasi larutan glukosa dan kalsium klorida. TSS tertinggi terdapat pada coating sari buah jeruk dengan perlakuan kalsium klorida $0,7 \%$ dan larutan glukosa $15^{\circ}$ brix. TSS terendah terdapat pada coating sari buah jeruk dengan perlakuan kalsium klorida $0,6 \%$ dan larutan glukosa $15^{\circ}$ brix. Pada coating sari buah jeruk yang disimpan dalam larutan glukosa diduga terjadi difusi zat-zat padat keluar sistem sehingga padatan tersuspensi dalam coating sari buah jeruk mengalami penurunan. Difusi yang diakibatkan adanya perbedaan konsentrasi glukosa juga dipengaruhi oleh kalsium klorida yang membentuk coating sari buah jeruk. Semakin tinggi kalsium klorida, maka membran coating sari buah jeruk semakin kuat sehingga zat-zat padat yang terdifusi sedikit dan padatan tersuspensi dalam coating sari buah jeruk lebih tinggi. Berdasarkan analisis T-student, penurunan TSS dalam coating sari buah jeruk tidak berbeda nyata dengan TSS campuran sari buah jeruk dan natrium alginate.

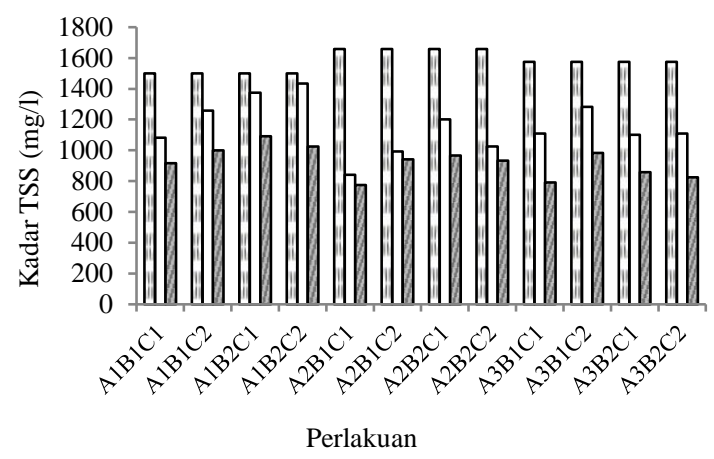

\begin{tabular}{|c|c|c|c|c|c|}
\hline \multicolumn{6}{|c|}{ 口Campuran Sari jeruk + Alginat } \\
\hline \multicolumn{6}{|c|}{ Keterangan: } \\
\hline A1 & : & Natrium alginat $0,6 \%$ & B2 & : & $\begin{array}{l}\text { Kalsium } \\
\text { klorida } 0,7 \%\end{array}$ \\
\hline B1 & : & Kalsium klorida $0,6 \%$ & $\mathrm{C} 2$ & : & $\begin{array}{l}\text { Larutan } \\
\text { glukosa } 22,5 \\
\text { obrix }\end{array}$ \\
\hline $\mathrm{C} 1$ & : & Larutan glukosa $15^{\circ}$ brix & A3 & : & $\begin{array}{l}\text { Natrium } \\
\text { alginat } 0,8 \%\end{array}$ \\
\hline A2 & . & Natrium alginat $0,7 \%$ & & & \\
\hline
\end{tabular}

Gambar 6. Histogram kadar total suspended solids (TSS) (mg/L) campuran sari buah jeruk dan natrium alginat, coating sari buah jeruk dalam larutan glukosa pada jam ke-0 dan ke-3

\section{Uji Organoleptik}

Aroma

Aroma merupakan salah satu faktor penting dalam menentukan kualitas bahan makanan. Aroma dari coating sari buah jeruk dipengaruhi oleh karakteristik buah jeruk dan glukosa. Coating sari buah jeruk Medan yang disukai panelis berdasarkan aroma adalah produk coating sari buah jeruk dengan perlakuan konsentrasi natrium alginat dan kalsium klorida berturut-turut 0,8 dan $0,7 \%$, serta perendaman dalam larutan glukosa $15^{\circ}$ brix (A3B2C1) dengan tingkat kesukaan sebesar 53,33\%. Aroma coating sari buah jeruk didominasi oleh aroma khas jeruk Medan, walaupun selama proses pembuatan terdapat komponen volatil aroma yang hilang. Gel agent berperan memerangkap flavor dan menghambat proses terlepasnya aroma dari sistem emulsi. Panelis cenderung menyukai coating sari buah jeruk dengan konsentrasi natrium alginat $0,8 \%$. Pada konsentrasi natrium alginat $0,8 \%$, flavor jeruk pada coating lebih menonjol karena mampu memerangkap flavor lebih kuat dibandingkan natrium alginat 0,6 dan $0,7 \%$.

\section{Warna}

Warna merupakan salah satu faktor visual yang menentukan penerimaan panelis terhadap suatu produk. Warna coating sari buah jeruk Medan dipengaruhi oleh warna kuning jeruk Medan. Produk yang paling disukai panelis berdasarkan warna adalah produk coating sari buah jeruk dengan perlakuan konsentrasi natrium alginat dan kalsium klorida berturut-turut 0,8 dan $0,7 \%$, serta perendaman dalam larutan glukosa $22,5^{\circ} \mathrm{brix}$ (A3B2C2). Respon kesukaan panelis yang diperoleh berdasarkan jumlah kumulatif pernyataan suka dan sangat suka sebesar $66,67 \%$. Warna coating sari buah jeruk dipengaruhi oleh perendaman dalam larutan glukosa, dimana warna coating terlihat lebih mengkilap. Kesukaan panelis terhadap coating sari buah jeruk A3B2C2 menunjukkan bahwa larutan glukosa $22,5^{\circ}$ brix memberikan pengaruh warna yang lebih baik dibandingkan dengan larutan glukosa $15^{\circ}$ brix

\section{Bentuk}

Produk yang paling disukai panelis berdasarkan bentuk adalah produk coating sari buah jeruk A3B2C1. Respon kesukaan panelis yang diperoleh berdasarkan jumlah kumulatif pernyataan suka dan sangat suka sebesar adalah 73,33\%. Penggunaan natrium alginat dan kalsium klorida sangat mempengaruhi bentuk coating sari buah jeruk yang dihasilkan. Coating sari buah jeruk dengan penggunaan natrium alginat $0,8 \%$ menghasilkan bentuk coating lebih cenderung bulat dan stabil sehingga lebih menarik. Sedangkan coating sari buah jeruk dengan natrium alginat $0,6 \%$ tidak disukai panelis karena bentuknya yang tidak bulat sempurna dan tidak cukup stabil. Peningkatan konsentrasi natrium alginat akan meningkatkan kekentalan. Semakin tinggi daya ikat air dan kekentalannya, makin besar pula penguatan struktur gelnya sehingga bentuk coating sari buah jeruk yang dihasilkan lebih stabil.

\section{Kekenyalan}

Nilai kekenyalan dipengaruhi oleh banyaknya natrium alginat yang ditambahkan. Semakin banyak natrium alginat yang ditambahkan dalam formula coating sari buah jeruk, kekenyalan coating cenderung naik. Coating sari buah jeruk yang disukai panelis berdasarkan kekenyalannya 
adalah produk dengan perlakuan A3B2C1. Respon kesukaan panelis yang diperoleh berdasarkan jumlah kumulatif pernyataan suka dan sangat suka sebesar $66,67 \%$. Panelis cenderung menyukai coating sari buah jeruk dengan penambahan natrium alginat sebesar 0,8\% karena menghasilkan coating sari buah jeruk yang lebih kenyal dan struktur gel yang kuat. Umumnya penguatan struktur gel erat hubungannya dengan kemampuan daya ikat air oleh natrium alginat dan kekentalannya (rasio natrium alginat dan sari buah jeruk). Semakin tinggi daya ikat air dan kekentalannya, makin besar pula penguatan struktur gelnya.

\section{Rasa}

Coating sari buah jeruk yang disukai panelis berdasarkan rasa adalah produk drengan perlakuan A3B2C1. Respon kesukaan panelis yang diperoleh berdasarkan jumlah kumulatif pernyataan suka dan sangat suka sebesar $60 \%$. Pengaruh rasa coating sari buah jeruk lebih banyak didominasi oleh rasa jeruk itu sendiri dan larutan glukosa. Jeruk Medan memiliki rasa manis dengan sedikit rasa asam. Coating sari buah jeruk A3B2C1 memiliki kadar vitamin $\mathrm{C}$ sebesar $37,4 \mathrm{mg} / 100 \mathrm{~g}$ bahan, total asam $148 \mathrm{mg} / 100 \mathrm{~g}$ bahan, dan total gula 6,56\%. Kadar vitamin $\mathrm{C}$ dan total asam coating sari buah jeruk A3B2C1 cenderung lebih tinggi dibandingkan dengan kadar vitamin $\mathrm{C}$ dan total asam coating sari buah jeruk perlakuan lainnya. Panelis menyukai coating sari buah jeruk dengan tingkat kemasaman yang cenderung tinggi. Adanya larutan glukosa sebagai media penyimpan memberikan pengaruh rasa manis pada coating sari buah jeruk. Panelis cenderung menyukai coating sari buah jeruk dengan tingkat kemanisan yang tidak terlalu tinggi, yaitu dalam larutan glukosa $15^{\circ}$ brix. Hal ini juga terlihat dari total gula coating sari buah jeruk A3B2C1 yang cenderung lebih rendah dibandingkan dengan perlakuan lainnya. Natrium alginat tidak memiliki rasa yang khas atau memiliki rasa yang netral sehingga penambahan natrium alginat dalam formulasi coating sari buah jeruk dengan kisaran 0,6-0,8\% tidak memberikan pengaruh yang berarti terhadap rasa coating.

\section{After Taste}

After taste adalah rasa yang timbul setelah bahan habis dalam mulut. Coating yang disukai panelis berdasarkan after taste adalah produk coating sari buah jeruk A3B2C2. Respon kesukaan panelis yang diperoleh berdasarkan jumlah kumulatif pernyataan suka dan sangat suka sebesar $40 \%$. After taste pada coating sari buah jeruk dapat timbul dari rasa buah jeruk dan larutan kalsium klorida. Sari buah jeruk yang diperas dari buah jeruk tidak dengan hati-hati akan menimbulkan rasa pahit yang mempengaruhi after taste dari coating sari buah jeruk. Coating sari buah jeruk A3B2C2 memiliki kadar vitamin $\mathrm{C}$ sebesar $37,4 \mathrm{mg} / 100 \mathrm{~g}$ bahan, total asam $152 \mathrm{mg} / 100 \mathrm{~g}$ bahan, dan total gula 6,63\%. Kadar total asam coating sari buah jeruk A3B2C2 merupakan kadar total asam tertinggi dibandingkan dengan perlakuan lainnya. Tingkat kemasaman jeruk Medan yang cukup tinggi dapat meninggalkan rasa sepet pada lidah. Rasa sepet dari coating sari buah jeruk tidak begitu terasa dikarenakan adanya larutan glukosa yang menutupi rasa sepet tersebut. Larutan glukosa $22,5^{\circ}$ brix diduga lebih dapat menutupi rasa sepet dari sari jeruk Medan dibandingkan larutan glukosa $15^{\circ}$ brix

\section{KESIMPULAN DAN SARAN}

\section{Kesimpulan}

Proses coating sari buah jeruk Medan yang baik harus memperhatikan penambahan konsentrasi natrium alginat dan kalsium klorida. Konsentrasi natrium alginat yang dapat membentuk coating adalah 0,$6 ; 0,7$, dan $0,8 \%$ dengan konsentrasi kalsium klorida 0,6 dan 0,7\%. Selain itu, waktu kontak campuran sari buah jeruk dan natrium alginat dalam larutan kalsium klorida 1-2 menit untuk mendapatkan coating yang tidak lembek dan tidak terlalu keras.

Mutu produk coating sari buah jeruk dalam larutan glukosa jam ke-0 berdasarkan vitamin C, total asam, total gula, dan total suspended solids (TSS) berturut-turut berkisar 33-39,6 mg/100g bahan, 88-152 mg/100 g bahan, 5,40-8,47 \% dan $841,67-1433,33 \mathrm{mg} / \mathrm{L}$. Mutu produk coating sari buah jeruk dalam larutan glukosa jam ke-3 memiliki kandungan vitamin C 24,2 -35,2 mg/100 g bahan, total asam $60-92 \mathrm{mg} / 100 \mathrm{~g}$ bahan, total gula $6,97-$ 9,34\%, dan total suspended solids (TSS) 775-1025 $\mathrm{mg} / \mathrm{L}$

Formula terbaik untuk pembentukan coating sari buah jeruk berdasarkan uji organoleptik adalah natrium alginat $0,8 \%$, kalsium klorida $0,7 \%$, dan larutan glukosa $15^{\circ}$ brix (A3B2C1). Pada formula coating sari buah jeruk terbaik dihasilkan nilai vitamin C 48,4 mg/100 g bahan, total asam 112 $\mathrm{mg} / 100 \mathrm{~g}$ bahan, total gula $6,56 \%$, dan total suspended solids $1033,33 \mathrm{mg} / \mathrm{L}$. Formula terbaik ini menghasilkan coating sari buah jeruk dengan bentuk yang bulat stabil, kekenyalan yang tinggi, dan rasa yang lebih asam serta kadar vitamin $\mathrm{C}$ yang tinggi.

\section{Saran}

Produk coating sari buah merupakan inovasi produk baru sehingga penelitian lebih lanjut mengenai produk ini perlu dilakukan untuk jenis buah yang lainnya.

\section{DAFTAR PUSTAKA}

AOAC. 1997. Official Methodsof Analysis. Association of Official Analytical Chemist Inc, Washington DC. 
Badan Pusat Statistik. 2012. Produksi Buah-Buahan di Indonesia. Badan Pusat Statistik dan Direktorat Jenderal Hortikultura.

Brownlee IA, Allen A, Pearson JP, Dettmar PW, Havler ME, Atherton MR. 2005. Alginate as a source of dietary fiber. Critical Reviews in Food Science and Nutrition 45(6): 497-510.

Dubois M, Gilles KA, Hamilton JK, Rebers PA, Smith F. 1956. Colorimetric method for determination of sugar and related substance. Analytical Chemistry. 28(3): 350-356.

Gardjito M dan Wardana AS. 2003. Hortikultura Teknik Analisis Pasca Panen. Penerbit Trans Media Mitra Printika, Yogyakarta.

Hill B. 2009. Molecular Gastronomy: Research And Experience. International Specialised Skills Institute, Melbourne. ISS Institute 101/685 Burke Road Camberwell 3124 Australia

Josef E, Zilberman M, dan Bianco-Peled H. 2010. Composite alginate hydrogels: an innovative approach for the controlled release of hydrophobic drugs. Acta Biomaterialia . 6(12): 4642-4649.

Li Y, Hu M, Du Y, Xiao H, dan McClements DJ 2011. Control of lipase digestibility of emulsified lipids by encapsulation within calcium alginate beads. Food Hydrocolloids 25(1):122-130.

Kaban J, Bangun H, Dawolo AK, Daniel. 2006. Pembuatan membran kompleks polielektrolit alginat kitosan. Jurnal Sains Kimia. 10 (1): 10-16.

Khotimchenko YS dan Khotimchenko MY. 2004. Healing and preventive effects of calcium alginate on carbontetrachloride induced liver injury in rats. Marine Drugs. 2 (3): 108-122.

Kirk dan Othmer. 1994. Encyclopedia of chemical technology. Fourth Edition. Volume 12. John Wiley \& Sons, New York. 1091 pp.

Mc.Hugh DJ. 2003. A guide to the seaweed industry. FAO Fisheries Technical Paper No. 441.

Okezie BO dan Bello AB. 1988. Physicochemical and Functional Properties of Winged Bean Flour and Isolate Compared with Soy Isolate. Journal Food Science. 53:2.

Smidsrod O dan Draget KI. 1996. Chemistry and physical properties of alginates. Carbohyd. Eur. 14:7.

This H. 2006. Food for tomorrow? How the scientific discipline of molecular gastronomy could change the way we eat. EMBO reports. 7(11): 1062-1066. 